\title{
IMPLICATIONS OF PALEOSEISMOLOGY IN SEISMIC HAZARD ANALYSIS IN NW CRETE AND KYTHIRA STRAIT (GREECE) C. ANDREOU ${ }^{1}$, V. MOUSLOPOULOU ${ }^{1}$, I. FOUNTOULIS ${ }^{1}$, K. ATAKAN ${ }^{2}$
}

\begin{abstract}
The scope of this paper is to study how geological data contribute to hazard analysis and the extent to which they can be incorporated in the existing hazard models. For this reason the study area was divided into area source zones and the paleoseismological data collected and studied on the Kera fault zone, in Chania, Crete, were taken into account. The seismic hazard was calculated with CRISIS99, using a combination of the Poissonian and the characteristic earthquake model. The data from the Kera fault affect slightly the calculation of seismic hazard. It is suggested that more paleoseismological data and a good attenuation relationship for the area, would lead to the development of hazard models capable to incorporate geological information and it would improve the quality of seismic hazard analysis.
\end{abstract}

KEY WORDS: Hazard analysis, paleoseismology, active fault, Poissonian distribution, characteristic earthquake.

\section{INTRODUCTION}

The work presented in this paper concerns an effort to incorporate paleoseismological data in seismic hazard analysis. The study area includes western Crete and Kythira strait (Fig.1). It is particularly interesting because it is located adjacent to the trench of the Hellenic arc-trench system. The island of Crete is located exactly where the arc changes direction from NW-SE, on the western side, to NE-SW in the east. Tectonic data such as slip rate, recurrence interval, elapsed time, displacement per event and fault geometry contribute to hazard analysis through various hazard models. The contribution of paleoseismic data to hazard analysis and to neotectonic research varies in importance within different tectonic environments and depending on the model used. In this paper, geological information derived from the investigation of an active fault studied by Mouslopoulou et al., (2000) was used to estimate the maximum magnitude and recurrence interval from field measurements and earthquake age respectively.

\section{DATA USED}

\section{a) Earthquake catalogue}

Seismicity data are the basis of a seismic hazard analysis, although it covers very short time periods when compared to geological data. This study is based on a catalogue provided and compiled from the Geodynamic Institute of the National Observatory of Athens. The compilation is based on the following catalogues:

From 1901 until 1963, the catalogue by Macropoulos and Burton (1981) is used, and magnitudes are estimated as Ms.

From 1964 until 1999 the catalogue comprises of the instrumental records from the National Observatory of Athens. All magnitudes were already converted to Ms, so, there was no need for further convertion in the context of this study.

The historical catalogue by Papadopoulos and Vassilopoulou (1998), is also taken into account.

The use of Ms magnitude is justified for the purpose of this analysis as the range of magnitudes used (4.57.4) is well represented by Ms scale. Ms saturates at about 7.0.

The catalogue comprises of 24.563 events in the area: $34.00^{\prime} \mathrm{I}-38.00^{\prime} \mathrm{IN}$ and $20.00^{\prime} \mathrm{I}-28.00^{\prime} \mathrm{IE}$. The maximum magnitude for the entire catalogue (in this region) is 7.4 and the minimum around 3.0. The reliability of the source parameters defined by the Geodynamic institute of Athens, has been improved considerably during the

\footnotetext{
1. University of Athens, Faculty of Geology Dept of Dynamic Tectonic Applied Geology, Panepistimiopolis Zografou 15784 Athens, Greece (fountoulis@geol.uoa.gr)

2. Institute of Solid Earth Physics, Univ. of Bergen, Norway (Kuvvet.Atakan@ifj.uib.no)
} 
present decade. During the last 15 years, earthquakes are located with a horizontal accuracy of $15-20 \mathrm{~km}$, when there is no important azimuthal gap. Focal depth is defined with an accuracy of $\pm 20 \mathrm{~km}$. In the area of study, the error is likely to be greater, because of the large azimuthal gap of the seismic network and the complicated structure which results in various ways of absorption and geometrical spreading along different paths (Andreou, 2000).

Fig.1: The study area, including the epicentres of the complete part of the catalogue, the active faults (Lyberis,

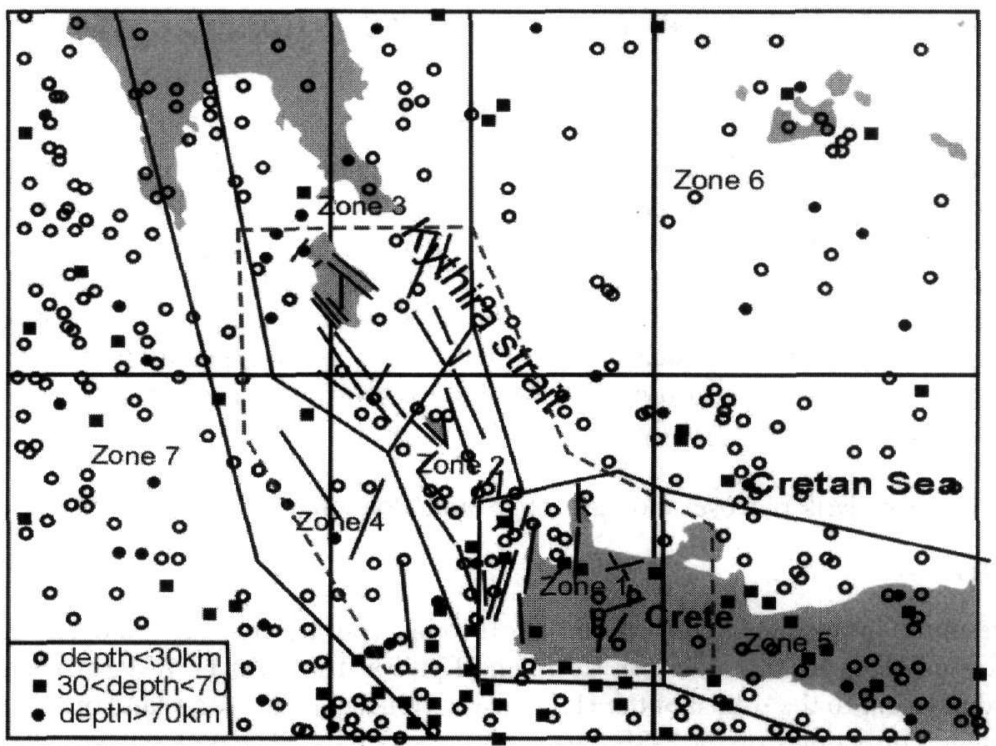

Angelier et al., 1992), the area sources, and the polygone for which, hazard is calculated.

\section{b) paleoseismological investigation on the kera fault zone}

The results of the study on the Kera fault zone (Mouslopoulou V. et al. 2000) provided the basis for the definition of recurrence intervals and slip rate in hazard analysis. The fault zone is located close to the village of Kera, southeast of Kastelli. The Kera fault represents the $5 \mathrm{~km}$ long middle segment of a N-S orientated fault system, which reaches a total of $30 \mathrm{~km}$. The strike of the fault is $036^{\prime} \mathrm{I}-045^{\prime} \mathrm{I} \mathrm{N}$, the dip is $70^{\prime} \mathrm{I}-78^{\prime} \mathrm{I} \mathrm{NW}$ and the slip is $20^{\circ}-24^{\circ} \mathrm{WNW}$. For the three most recent events that were identified, the estimation of the initial scarp height and maximum magnitudes are presented in the table below:

Table 1: The "initial scarp height" for the Kera fault (Mouslopoulou V. et al 2000).

\begin{tabular}{|l|l|l|}
\hline EVENT & $\begin{array}{l}\text { "initial scarp } \\
\text { height" }\end{array}$ & Maximum magnitude \\
\hline 1 & $2.4 \mathrm{~m}$ & $6.8 \mathrm{M}$ \\
\hline 2 & $3.4 \mathrm{~m}$ & $7 \mathrm{M}$ \\
\hline 3 & $0.5 \mathrm{~m}$ & $6.4 \mathrm{M}$ \\
\hline
\end{tabular}

The total initial scarp height measured is $6.3 \mathrm{~m}$. The scarp height can approximate the displacement on the fault scarp. Assuming that the last 3 events happened in Holocene, an average slip rate of $0.63 \mathrm{~mm} / \mathrm{year}$ is estimated. Based on these results, a mean recurrence interval of 10.000:3 $=\sim 3.300$ years can be calculated for these three events.

In hazard analysis, a recurrence interval of 3.000 years was assumed for a characteristic earthquake of magnitude 6.5 (see table 7.2). The mom_slip program (H. Bungum, pers. com.) provides a way to evaluate this recurrence period, given the slip rate of $0.63 \mathrm{~mm} / \mathrm{yr}$. 


\section{c) The distribution of active faults}

The distribution of active faults in the area of interest, both on land and offshore, is taken from Lyberis, Angelier et al (1982). The identification of active faults is mainly based on a detailed bathymetry map.

\section{METHOD OF APPROACH}

\section{a) Processing the earthquake catalogue}

The completeness of this catalogue has been checked with SEISAN (Havskov, 1999) program and with magnitude-frequency diagrams. The results of the completeness analysis are presented in table 2

Table 2: Results of completeness analysis

\begin{tabular}{|c|c|}
\hline $\begin{array}{c}\text { Range of } \\
\text { Magnitudes }\end{array}$ & $\begin{array}{c}\text { Complete since the } \\
\text { year }\end{array}$ \\
\hline Ms $\geq 4.0$ & 1978 \\
\hline Ms $\geq 4.5$ & 1964 \\
\hline Ms $\geq 5.0$ & 1950 \\
\hline Ms $\geq 6.0$ & 1910 \\
\hline
\end{tabular}

The area of interest for the hazard analysis is: $35.00-37.00 \mathrm{~N}$ and $22.00-24.00 \mathrm{E}$.

The complete part of the catalogue in this area comprises of 332 events (1964-1999) of magnitude Ms $>4.5$.

\section{b) Definition of lower and upper bound magnitudes}

- The minimum magnitude assigned to all sources is 4.5 i.e.: the threshold magnitude above which the catalogue is considered complete.

- Max. magnitudes are estimated for each zone, using the regression by Wells and Coppersmith (1994), which yields the equation $\mathrm{M}=5.08+1.16 * \log (\mathrm{SRL})$ and measuring the fault lengths from Lyberis and Angelier (1982).

Table 3: The maximum magnitude derived from the historical catalogue and from the empirical relationship by Wells and Coppersmith (1994).

\begin{tabular}{|l|l|l|l|l|}
\hline $\begin{array}{l}\text { Seismic } \\
\text { Source }\end{array}$ & $\begin{array}{l}\text { Mmax } \\
\text { (Ms) } \\
\text { observed }\end{array}$ & $\begin{array}{l}\text { Mmax (Ms) } \\
\text { from }\end{array}$ & $\begin{array}{l}\text { Maximum } \\
\text { fault } \\
\text { catalogue } \\
\text { Length } \\
(\mathrm{km})\end{array}$ & $\begin{array}{l}\text { Mmax (Mw) } \\
\text { Wells \& } \\
\text { Coppersmith } \\
(1994)\end{array}$ \\
\hline $\begin{array}{l}\text { W.Crete } \\
\text { zone }\end{array}$ & 6.6 & 6.8 & 44 & 7 \\
\hline $\begin{array}{l}\text { Antikythira } \\
\text { zone }\end{array}$ & 5 & $6.85 \pm 0.65$ & 28 & 6.7 \\
\hline $\begin{array}{l}\text { Kythira } \\
\text { zone }\end{array}$ & 6.1 & & 50 & 7.0 \\
\hline Outer zone & 6.1 & $8.39 \pm 0.2$ & 28 & 6.7 \\
\hline
\end{tabular}

\section{c) Identification of seismic source zones}

A seismic source zone is defined as a seismically homogeneous area, in which every point within the source zone is assumed to have the same probability of being the epicentre of a future earthquake. The identification of sources is done using both geological and seismological criteria and it is based on the following basic principles.

- The zones should be extended outside the polygon in which hazard is computed in order to cover all areas where seismicity can have influence on the seismic hazard, which normally means $200-300 \mathrm{~km}$ around the sites.

- They should be defined as areas with homogeneous seismic characteristics.

- The existence of a boundary is decided based on the most dominant tectonic or seismic features, taking into account the location uncertainty of the earthquakes as well as the uncertainties of the fault location -especially offshore. In this case the en-echelon arrangement of the offshore faults, in Kythira strait was the basis 
of defining the Kythira and Antikythira area sources.

- Zonation should allow for differences in focal depth. In this case, two zones defined as dipping planes, account only for the deepest earthquakes, which are related to subduction.

- For the areas where there is no mapping of faults, 3 background zones are defined to model the earthquakes of these areas.

The zones 1-7 include events shallower than $30 \mathrm{~km}$, which are not related to the subduction. The mean depth used for these zones is $15 \mathrm{Km}$ since the resolution in the depth of the epicentres does not permit to assign different depth to each zone. Zones 8 and 9 include the deeper earthquakes that are probably related to the subduction. The depth distribution of the earthquakes indicates that the depth increases towards NE direction. However the subduction zone cannot be clearly identified.

The zones 1-9 are referred to as (Fig.1):Zone 1: W. Crete, Zone 2: Antikythira Zone 3:Kythira, zone 4:outer zone, Zone 5- background-1, zone 6: background-2, Zone 7: background-3, Zone 8:subduction-1, zone 9:subduction-2.

\section{c) Attenuation relationship}

Many relationships were initially considered but the ones chosen for the purposes of this paper the attenuation relationship used are Theodoulides and Papazahos (1992) and Sadigh (1997). Theodoulides and Papazahos (1992) was preferred because it is partly based on Greek data. Sadigh's relationship is derived for a seismotectonic environment very different than that of the study area (strike-slip and reverse faults). However, it is chosen for this paper because it is the one used in the assessment of earthquake hazard in Turkey and neighbouring regions-including Greece- which is conducted in connection with the Global Seismic Hazard Assessment programme (GSHAP). Ideally, in order to judge and compare properly all relations and chose the "best", one should know the data on which each one is based.

\section{d) Input models}

The assessment of seismic hazard was made, using different models and different attenuation laws, in order to compare the results. In all models, the hazard is computed for the polygon shown in Fig.1. This polygon encloses the area where both mapped faults and earthquake records exist. The sites of Kastelli and Chania, which are very important in this study since they consist the most densely populated towns in the area, are included in this polygon, as well as the islands of Kythira and Antikythira.

- model 1- Poisonnian: All 9 area sources are included in this model. The parameters required in CRISIS99 for the Poissonian model are shown in Table 4.

- model 2- Characteristic earthquake model: The parameters required for the characteristic earthquake model in CRISIS99 (Ordaz, 1991) are presented in table5

The time elapsed since the last occurrence is chosen as a conservative rough assumption. In the historical catalogue of Papadopoulos and Vassilopoulou (1998) for Western Crete and Kythira strait, there is no event that could be directly connected to Kera fault. This might be an indication that the elapsed time since the last event is large because the catalogue is including earthquakes since antiquity (A.D. 365). However, the possibility that large historical events in the area still remain unknown should not be excluded. $\mathrm{D}(\mathrm{N})$ and $\mathrm{F}(\mathrm{N})$ are parameters defining the expected magnitude as a function of time, as in the slip-predictable model. The standard deviation is that of Wells and Coppersmith (1994).

Table 6 summarises the models described above.

\section{e) mom_slip program: fault activity from slip-rates}

Hilmar Bungum (pers. com.) has refined and in some extend developed some utility programs which are very useful in quantifying earthquake activity on faults with sensitivity tests.

Table 7 shows the parameters used in this program and the values defined for the hazard analysis of this study. 
Table 4: Parameters for the Poissonian model

\begin{tabular}{|c|c|c|c|c|c|c|}
\hline $\begin{array}{l}\text { Seismic } \\
\text { Source }\end{array}$ & $\begin{array}{l}\text { events } \\
\text { since } \\
1964\end{array}$ & $\begin{array}{l}\text { Frequency } \\
\text { (events/ye } \\
\text { ar) }\end{array}$ & $\begin{array}{l}\text { Depth } \\
\text { avera } \\
\text { ge } \\
(\mathrm{km})\end{array}$ & $\begin{array}{l}\text { Bvalue } \\
\text { fixed }\end{array}$ & Mmin & $\begin{array}{l}\text { Mmax } \\
\text { (calculated } \\
\text { and } \\
\text { selected) }\end{array}$ \\
\hline $\begin{array}{l}\text { 1.W.Crete } \\
\text { zone }\end{array}$ & 18 & 0.510 & $\sim 15$ & 1.00 & 4.5 & 7.0 \\
\hline $\begin{array}{l}\text { 2. Antikythira } \\
\text { zone }\end{array}$ & 15 & 0.428 & $\sim 15$ & 1.00 & 4.5 & 6.7 \\
\hline $\begin{array}{l}\text { 3. Kythira } \\
\text { zone }\end{array}$ & 29 & 0.828 & $\sim 15$ & 1.00 & 4.5 & 7.0 \\
\hline 4. outer zone & 53 & 1.514 & $\sim 15$ & 1.00 & 4.5 & 6.7 \\
\hline 5.background1 & 55 & 1.500 & $\sim 15$ & 1.00 & 4.5 & 7.0 \\
\hline 6.background2 & 44 & 1.200 & $\sim 15$ & 1.00 & 4.5 & 6.5 \\
\hline 7.background3 & 113 & 3.228 & $\sim 15$ & 1.00 & 4.5 & 7.0 \\
\hline 8.subduction 1 & 21 & 0.600 & $0-35$ & 1.00 & 4.5 & 7.0 \\
\hline 9. subduction2 & 33 & 0.942 & $\begin{array}{l}35- \\
999\end{array}$ & 1.00 & 4.5 & 7.0 \\
\hline
\end{tabular}

Table 5: Parameters for the characteristic earthquake model

\begin{tabular}{|l|l|l|l|l|l|l|l|}
\hline $\begin{array}{l}\text { Seism. } \\
\text { Source }\end{array}$ & $\begin{array}{l}\text { Return } \\
\text { period } \\
\text { between } \\
\text { characte- } \\
\text { ristic } \\
\text { earth- } \\
\text { quakes }\end{array}$ & $\begin{array}{l}\text { Time } \\
\text { elapsed } \\
\text { since the } \\
\text { last } \\
\text { occurrence } \\
\text { of a } \\
\text { characteri } \\
\text { stic } \\
\text { earthquake }\end{array}$ & D (N) & F(N) & $\begin{array}{l}\text { Standard } \\
\text { deviation } \\
\text { of the } \\
\text { magnitude } \\
\text { of } \\
\text { characteri } \\
\text { stic } \\
\text { earthquake }\end{array}$ & $\begin{array}{l}\text { Minimum } \\
\text { possible } \\
\text { magnitude } \\
\text { of } \\
\text { characteri } \\
\text { stic } \\
\text { earthquake }\end{array}$ & $\begin{array}{l}\text { Maximum } \\
\text { magnitude } \\
\text { of } \\
\text { characteri } \\
\text { stic } \\
\text { earthquake }\end{array}$ \\
\hline $\begin{array}{l}\text { Kera } \\
\text { fault } \\
\text { line }\end{array}$ & 3000 & 680 & 6.5 & 0.0 & 0.28 & 6.5 & 7.0 \\
\hline
\end{tabular}

Table 6: Summary of the input models

\begin{tabular}{|c|c|c|c|}
\hline & \multicolumn{3}{|c|}{ P A R A M E TE R S } \\
\hline MODEL & Attenuation model & Sources & $\begin{array}{l}\text { Earthquake } \\
\text { occurrence process }\end{array}$ \\
\hline $1 \mathrm{a}$ & $\begin{array}{l}\text { Papazachos } \\
\text { Theodoulides } \\
\text { (1992) }\end{array}$ & All area-sources & Poissonian \\
\hline $1 b$ & Sadigh (1997) & All area-sources & Poissonian \\
\hline $2 a$ & $\begin{array}{l}\text { Papazachos and } \\
\text { Theodoulides } \\
\text { (1992) }\end{array}$ & $\begin{array}{l}\text { All area-sources } \\
\text { and Kera fault- } \\
\text { line }\end{array}$ & $\begin{array}{l}\text { Poissonian and } \\
\text { characteristic } \\
\text { earthquake }\end{array}$ \\
\hline $2 \mathrm{~b}$ & Sadigh (1997) & $\begin{array}{ll}\text { All } & \text { area-sources } \\
\text { and Kera fault- } \\
\text { line }\end{array}$ & $\begin{array}{l}\text { Poissonian and } \\
\text { characteristic } \\
\text { earthquake }\end{array}$ \\
\hline
\end{tabular}

The program runs for a reference magnitude of 4.5 and the result is that a return period of 3.000 years for a 6.6 magnitude is required to produce the slip rate of $0.63 \mathrm{~mm} / \mathrm{years}$. 
Table 7: The input parameters of the mom_slip program

\begin{tabular}{|l|l|}
\hline \multicolumn{1}{|c|}{ RARAMETER } & \multicolumn{1}{|c|}{ VALUES } \\
\hline Slip rate (mm/yr) & 0.63 \\
\hline $\begin{array}{l}\text { Fault length } \\
\text { min/max/increment (km) }\end{array}$ & 5.0050 .002 .50 \\
\hline b-value in log(N)=a-bM fange & 0.60 (common for faults) \\
\hline $\begin{array}{l}\text { Reference magnitude for N-value } \\
\text { calculation }\end{array}$ & 4.50 \\
\hline $\begin{array}{l}\text { Magnitude type (1:Mw, 2:Ms, 3:User } \\
\text { defined) }\end{array}$ & 2 \\
\hline $\begin{array}{l}\text { Fault area / maximum mag. relation: } \\
\text { log (Af)=a+b*Mmax }\end{array}$ & -3.490 .91 \\
\hline Slip / fault length (aspect) ratio & $0.600 \mathrm{E}-04$ \\
\hline Fault length / width factor (a) & $1.5(30: 20)$ \\
\hline Shear modulus ( $\mu$ ) & $\begin{array}{l}0.330 \mathrm{E}+12 \\
\text { crustal value) }\end{array}$ \\
\hline
\end{tabular}

\section{RESULTS}

For all the models, a map is produced showing the values of Peak ground acceleration for a return period of 475 years (Fig 2). The table below shows the P.G.A. values for the sites of Kastelli and Chania.

Table 8: Summary of the results for the sites of Kastelli and Chania

\begin{tabular}{|l|l|l|l|l|}
\hline \multirow{2}{*}{} & \multicolumn{4}{|l|}{$\begin{array}{l}\text { Peak Ground Acceleration (475 } \\
\text { years) }\end{array}$} \\
\cline { 2 - 5 } & $\begin{array}{l}\text { Model } / \text { sec }^{2} \\
1 \mathrm{a}\end{array}$ & $\begin{array}{l}\text { Model } \\
1 \mathrm{~b}\end{array}$ & $\begin{array}{l}\text { Model } \\
2 \mathrm{a}\end{array}$ & $\begin{array}{l}\text { Model } \\
\text { 2b }\end{array}$ \\
\hline Kastel1i & 465 & 300 & 470 & 310 \\
\hline Chania & 420 & 290 & 420 & 290 \\
\hline
\end{tabular}

\section{DISCUSSION AND CONCLUSIONS}

Geological data were incorporated in this study through the following ways:

a) Rupture length-magnitude relationships were used to infer the maximum magnitude, which was used as an input to hazard assessment (Table 3)

b) The recurrence interval for the characteristic earthquake model was calculated from the cumulative slip on the Trenches investigated on the Kera fault. Estimations yielded a recurrence interval of approximately 3000 years for a characteristic earthquake of magnitude 6.5 .

The results of the different models used as an input to hazard assessments lead us to the conclusion that the extent to which geological information contributes to the assessment of hazard in an area depends on the quantity and quality of data collected and also on the means (the model) by which the data are interpreted. The use of Poissonian model, although many authors consider it, as the most reliable existing model, does not leave much space for fault specific assessments. The use of characteristic earthquake model is far more fault-specific but it is based on a concept, which has been subjected to extensive debate and on restricted data.

In this study, the paleoseismological data were incorporated through a combination of the Poissonian and the characteristic earthquake model. The reason for doing so, is to be able to use the fault lines instead of area sources and at the same time take into consideration the subduction by including two dipping planes (areasources) with the average dip of the Benioff zone in the area. Of course, in this case, the results reflect the drawbacks of both models but the combination of models is an approach used by many authors (Youngs and Coppersmith, 1985). If the hypothesis of a seismic gap is valid (e.g. Wyss 1980,1981), Poissonian model would lead to an underestimation of hazard in the area of Kythira strait. The information derived on the Kera fault, increased the hazard in Kastelli by 5-10 gal. Apparently, if more seismological data, from other active faults in the area were available their influence to the final result would be even greater. 

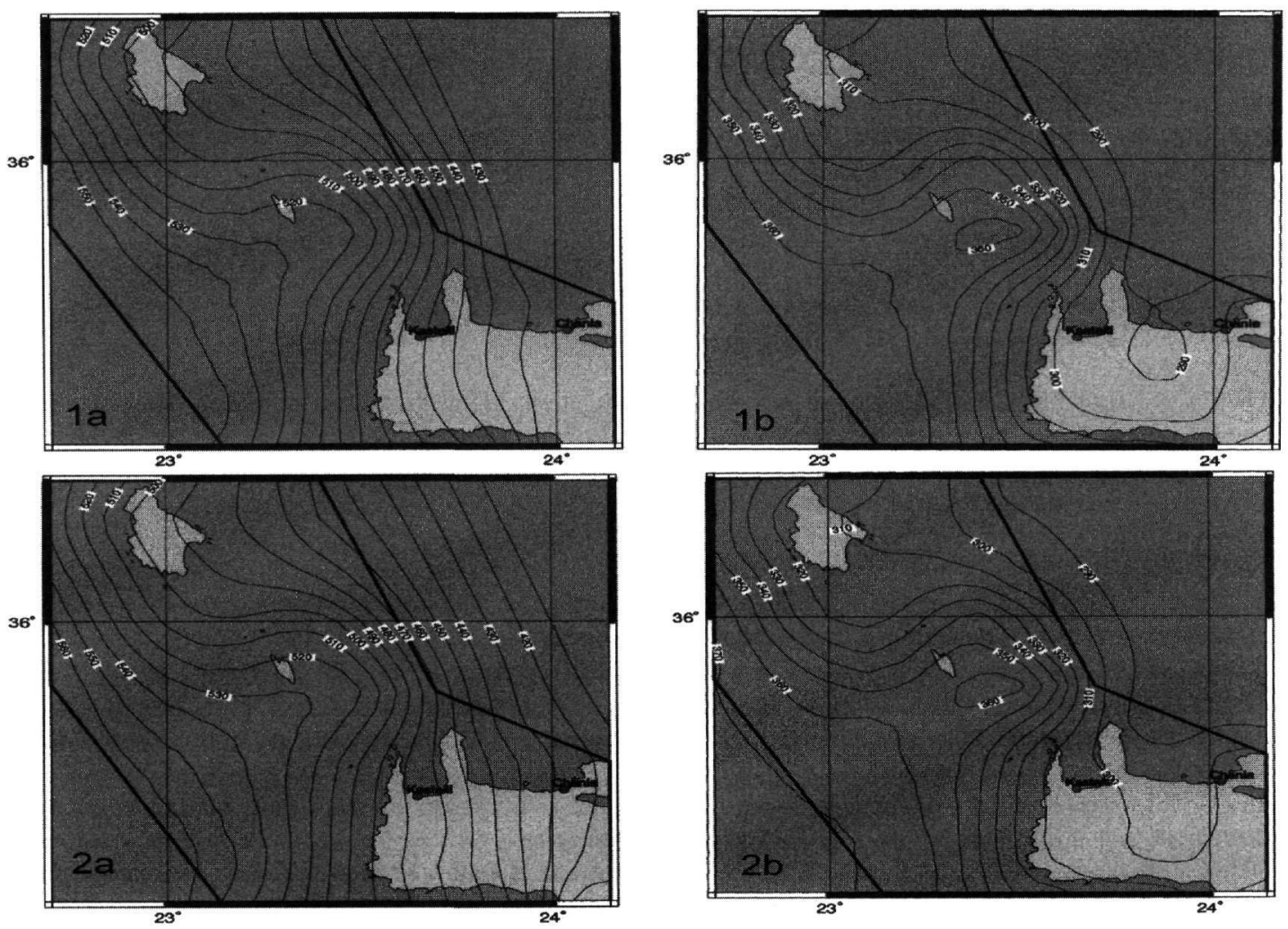

Fig 2: Hazard maps for models $1 a, 1 b, 2 a, 2 b$ respectively. The resulting curves show Peak Ground Acceleration calculated with Sadigh (1997) relationship for a return period of 475 years. The curve intervals are 10 gal

The characteristic earthquake model is the only widely used model, which permits the incorporation of geological data. However, in this study, it would require data from many other active faults. Andreou (2000) extrapolated the results on the Kera fault to all the active faults in the area and applied the characteristic earthquake model. The results yielded were unreasonably high, a fact which reflected the lack of data and not the inefficiency of the model. Although the absolute values were obviously overestimated, they could indicate the different distribution of values when using this model. The use of more geological and paleoseismological information on the area would be required so that the results of these models would give a reliable estimation of the hazard on the area.

The Poissonian and the characteristic earthquake models are the most widely used but not the only existing ways of approaching hazard analyses. Scientists have proposed various fault behaviour and eathquake recurrence models as well as different ways of approaches in order to improve future hazard analyses. Which of all the proposed distributions, fault behaviour models and different approaches is appropriate for earthquake recurrence or whether different types of faults obey different distributions is still uncertain and should be addressed in the future in more detail. In order to address this problem, collection of additional paleoseismological data is required in collaboration with neotectonic studies. The acquisition of more such data in the future would permit a better evaluation of the various models proposed and could lead to the creation of a behavioural model which will incorporate geological data in a reliable way that can be used in future seismic hazard estimations.

The absolute values of ground motion depend on the attenuation relationship, regardless of the model used. The relationships used in this study yielded very different results. None of these relations is based on data from the study area. The results derived with Papazachos and Theodoulides (1992) relationship are considered the most reliable among those used because the relationship is partly based on data from Greece. However, this relationship, too, accounts for the subduction using data from Japan and Alaska. The seismotectonic and crustal structure uniqueness of the study area illustrates the need to acquire a relationship with near-field strong motion data coming from this area. 


\section{REFERENCES}

AMBRASSEYS, N. N., 1981. On the long term seismicity of the Hellenic arc.

Boll. Teor. Geof. Appl. XXIII, 355-359.

ANDREOU C., 2000. Seismic Hazard Analysis Of Western Crete And Kythira Strait, Institute of Solid Earth Physics, University of Bergen, pp.1-180.

HAVSKOV J., 1999. The SEISAN earthquake analysis software for the IBM PC and SUN, institute of Solid Earth Physics, university of Bergen.

LYBERIS, N., ANGELIER, J. et al., 1982. Active deformation of a segment of arc: the strait of Kythira, Hellenic arc GREECE. Journal of Structural Geology, vol 4, No 3, 299-311.

MAKROPOULOS, K. and BURTON W., 1981. A catalogue of seismicity in Greece and adjacent areas. J.R. Astr. Soc., 65, pp. 741-762.

MOUSLOPOULOU et al., 2000. Paleoseismological investigations along the Kera Fault Zone, Western Crete: Implications for seismic hazard assessment, pp.1-130.

ORDAZ, M (1991). CRISIS 1999. Brief description of program CRISIS. Institute of Solid Earth Physics, University of Bergen, Norway, Internal Report, 16p.

PAPADOPOULOS G.A. and VASSILOPOULOU, A., 1998. Historical and Archaeological evidence of earthquakes and Tsunamis felt in the Kythira strait, Greece. Institute of Geodynamics, NOA publication No 9.

Pers. com. H. BUNGUM. Numerical modeling of fault activity, mom_slip and mom_rate programs.

SADIGH et. al. (1997). Attenuation Relationships for Shallow Crustal Earthquakes

Based on California Strong Motion Data, Seismological Research Letters, 68, January/February, 1997).

THEODOULIDES,N. and, PAPAZACHOS, B., 1992. Dependence of strong ground motion on magnitude, distance, site geology and macroseismic intensity for shallow earthquakes in Greece. Soil Dyn. \& Earth. Engn., 13, 317-343.

WELLS, D.L. and COPPERSMITH, K.J., 1994. Empirical relationships among magnitude, rupture length, rupture area, and surface displacement. Bull. Seism. Soc. Am., 84, 974-1784.

YOUNGS, R. R. and K.J. COPPERSMITH, 1985. Implications of fault slip rates and earthquake recurrence models to probabilistic seismic hazard estimates. Bull. Seism. Soc. Am., 75, 939-964. 